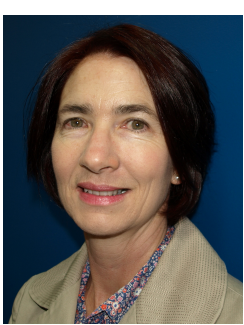

\title{
IF MINING CONFLICTS SUPPRESS THE RIGHT OF PUBLIC PARTICIPATION, THEN CAN MINING BE
} SUSTAINABLE?

\section{Judith Preston}

Solicitor, admitted to

Supreme Court of NSW and the NT

Mining of natural resources has surpassed agriculture as the basis for Australia's economy; but at what cost? It is essential to Australia's economic health to have access to a continuing income stream from a number of sources including minerals. However, there is a presumption - in both the political and resources sectors - that mining interests should trump all other interests, including social and environmental ones. A number of recent conflicts involving major mining projects in Australia and overseas have highlighted the fallacy of the claimed economic and social benefits, as well as the dangers to the community, the legal profession and the judiciary of suppressing public participation in the environmental impact assessment (EIA) process.

Any actions by the executive to exclude public participation in reviewing documentation related to resource management and extractive developments by legislative or policy changes such as the proposed new planning legislation in NSW and the new mining State Environmental Planning Policy (Mining Petroleum, Production and Extractive Industries) Amendment (Resource Significance) 2013 (Amended Mining SEPP), are retrogressive steps. The argument in this article is that, due to the often negative and large-scale impacts that mineral extraction developments may have on the community and the environment, mineral extraction developments should be subject to a rigorous EIA processes which incorporate effective and inclusive rights of public participation, especially in relation to major projects. Such rights should be enshrined in environmental legislation in the objects clause and in provisions granting standing for merit and judicial review and there should be a duty for the decisionmakers to properly consider public submissions. Such provisions may lead to revision of the development or its outright rejection. Furthermore, innovative policies, programmes and legislative reform should be drafted to protect public participation and the right to oppose inappropriate developments.

\section{Introduction}

Minerals are an intrinsic part of many products, from cosmetics to building materials, detergents, pharmaceuticals, electronics, glass and plastics. Modern life has come to rely upon these products, with global and domestic economies based on the wealth produced from these non-renewable resources. However, extracting and processing minerals comes with both positive and negative outcomes. The mineral extractive sector can create wealth, employment and trade opportunities but, conversely, it can lead to environmental impacts, including land degradation and pollution.

In the approval process for a mining project there appears to be an assumption that developments will be approved unless objectors demonstrate the flaws in the assumption. Bates argues 'political values are already weighted towards economic and social issues; and although environmental values are important, the prevailing assumption is that developments and growth should be allowed to proceed unless there are clearly proven reasons for limiting it'.

It has been argued that the term 'sustainable mining' is a paradox ${ }^{2}$ because mineral resources are finite and non-renewable. In an effort to, at least, place mining within a more sustainable framework there have been initiatives developed to examine mining sustainability and the performance of the industry. These include:

\footnotetext{
${ }^{1} \mathrm{G}$ Bates, Environmental Law in Australia (LexisNexis Butterworths, $7^{\text {th }}$ ed, 2010) 215.

${ }^{2}$ G M Mudd, 'The Environmental Sustainability of Mining in Australia: Key Mega-Trends and Looming Constraints' (2010) 35 Resources Policy $98,98$.
} 
the Global Mining Initiative; the Mining, Minerals and Sustainable Development Project; ${ }^{3}$ the 'Breaking New Ground' report; ${ }^{4}$ and the formation of the International Council on Mining and Metals.

However, even if mining companies approach their industry with a more eco-centric nuance or apply more sustainability standards, the long term costs of mining to present and future generations are generally not assessed accurately, and mining is 'becoming increasingly costly from an environmental perspective. ${ }^{5}$ As Mudd $^{6}$ discusses: generally the true environmental costs of mining are not accurately quantified and the short- and long-term effects on issues such as biodiversity, climate change and human rights fail to attract proper assessment. Environmental impact assessment (EIA) processes for mining are often inadequate and not assessed properly; increased risks of mining resources in remote sites are not adequately taken into account; the extent and longevity of damage caused to the environment as minerals from accessible mines are exhausted are not adequately taken into account; and the shift from underground to open cut mines is a cause for greater environmental impacts, with increases in noise levels, air and water pollution as well as waste rock. ${ }^{7}$

At present, legislation and governance are weighted in favour of supporting approval of mining projects, ${ }^{8}$ and excluding public participation that questions the need for the public purse and society to support an industry based on non-renewable resources. The consequences of successful action by the public to restrict or modify mining developments can be demonstrated by the Bulga Case, in which a resident's action group made an application in the Land and Environment Court of NSW against the approval of a mine extension for the Warkworth mine in the Hunter Valley (the Bulga case). The Court upheld the legitimacy of objections to the expansion of the coalmining site. ${ }^{9}$

However, following the Bulga case, public participation in environmental governance was reduced in state environmental planning policies and in proposed planning legislation, and there was a media backlash campaign encouraged by the mining lobby to criticise the democratic process and the role of judiciary to review executive action 'without fear or favour'. As reported by Lagan, ${ }^{10}$ corporate representatives of Warkworth's parent company, Rio Tinto, were able to arrange direct access to the highest political officer in NSW, the Premier, to complain about the outcome of a lawful review of the mining approval process and apply pressure for change in its favour. What happened in the aftermath of the Bulga case indicates an unhealthy trend towards restricting the right to participate in public life that contradicts international initiatives such as the Global Compact Network and the World Business Council for Sustainable Development 2050 Vision. ${ }^{11}$

\section{Sustainable development and mining projects}

Ecologically sustainable development (ESD) is one of the key concepts from the 1992 Rio Conference on Environment and Development (UNCED). ${ }^{12}$ Governments from 170 nations and many other delegates at UNCED produced a statement of general principles ('Rio Declaration'), Agenda 21 (an action plan) and two conventions on biodiversity and climate change. The Rio Declaration listed 27 principles to be used as a blueprint for achieving ESD. These include:

- $\quad$ Environmental protection must be an intrinsic part of development (Principle 4);

3 Ibid 99. See also International Institute for Environment and Development, Mining, Minerals and Sustainable Development 10 years on' (IIED) <http://www.iied.org/mining-minerals-sustainable-development-10-years-mmsd-10>.

${ }^{4}$ See, eg, International Institute for Environment and Development, 'Breaking New Ground' (The Report to the Mining, Minerals and Sustainable Development Project, IIED, May 2002); F Solomon, E Katz and R Lovel, 'Social dimension of mining: Research, Policy and Practice Challenges for the Minerals Industry in Australia' (2008) 33 Resources Policy 142, 142.

Mudd, above n 2, 114

${ }^{6}$ Ibid.

Ibid.

Bates, above $\mathrm{n} 1$.

${ }^{9}$ Bulga Milbrodale Progress Association v Minister for Planning and Infrastructure and Warkworth Mining Limited [2013] NSWLEC 48 (Preston CJ).

${ }^{10}$ B Lagan, 'What Happens With Rio Tinto, Stays With Rio Tinto' The Global Mail (online), 2 October 2013 <http://www.theglobalmail.org/feature/what-happens-with-rio-tinto-stays-with-rio-tinto/704/>.

${ }^{11}$ See, eg, United Nations, 'United Nations Global Compact' (21 February 2014) UN

<http://www.unglobalcompact.org/>; World Business Council for Sustainable Development, 'Vision 20' WBCSD

$<$ http://www.wbcsd.org/about.aspx>.

${ }^{12}$ United Nations Conference on Environment and Development (UNCED), Rio de Janiero, 4-14 June 1992. 
- Unsustainable human consumption and production methods must be changed (Principle 8);

- The needs of present and future generations must be taken into account in decision-making (Principle 3); and

- Effective environmental protection laws must be passed to give effect to the concepts of ESD (Principle 11).

One of the most relevant principles of ESD for the purposes of this article is Principle 10, which requires states to facilitate access to information and public participation in decision-making. Other principles include protecting biodiversity, the precautionary principle and the polluter pays principle. ESD is a concept that is accepted internationally - appearing in many international agreements and as a principle of customary international law. ${ }^{13}$ Australia has included ESD in policy initiatives and legislative reform. The Commonwealth government started the process in 1990 with a National Strategy for Ecologically Sustainable Development (NSESD), which was endorsed by all Australian states and territories in December 1992.

ESD has also become one of the primary criteria for environmental management as both an object of legislation and a compulsory consideration in environmental decision-making. Whilst there are differences between Commonwealth and state legislation on the definition of ESD, most are based on the definition in the NSESD and the 1992 Inter-Governmental Agreement on the Environment. For example, s 3A of the Environmental Protection and Biodiversity Act 1999 ('EPBC Act') makes reference to ESD principles in its objects. Section 136 of the EPBC Act directs the Minister to consider ESD as one of the matters to be taken into account in deciding on whether to approve an action.

In NSW, important environmental legislation, notably the Environmental Planning and Assessment Act 1979, ('EPA Act') and the Protection of the Environment Administration Act 1997 ('POEO Act'), incorporate ESD in terms of their respective objects and clauses, and in relation to exercising duties and discretions under the legislation. Significant NSW case law ${ }^{14}$ has given a broad interpretation to ESD, including the remarks of Preston CJ in Hub Action Group Inc v Minister for Planning:

[i]n order to achieve sustainability ... the grand strategy must be translated into action. This involves not only institutionalizing the principles of ecologically sustainable development in policies and laws but also ensuring that functions under those policies and laws are exercised in a way so as to promote and implement the principles of ecologically sustainable development. This involves good governance. ${ }^{15}$

Even though Australian environmental policies and legislation at Commonwealth and state levels subscribe to incorporating ESD into their principles, due to the priority of development (particularly mining developments), it is not effectively translated into practice. Australia's close relationship with mining and the benefits of mining to its economy are outlined in the next section.

Mark Halle, Vice President for the International Institute for Sustainable Development, highlights one of the key issues:

[s] ustainable development is a genuinely good idea. Why would you want a form of development that undermines the environment on which it is based that leads to more and more destruction of resources that leads to the undermining of the basis for human existence? Nobody in their right minds would want that. ${ }^{16}$

However, the actions that occurred following the Bulga case (discussed in more detail later), including the introduction of the State Environmental Planning Policy (Mining Petroleum Production and Extractive Industries) Amendment (Resource Significance) 2013 (Amended Mining SEPP), demonstrates a lack of commitment to Principle 10 of the Rio Declaration.

Mining developments can be consistent with ESD principles but only if there is a robust legislative and policy framework supporting an effective EIA process. The EIA process can ensure mining projects are consistent with ESD if there is a transparent and accountable process involving public participation for proper and

\footnotetext{
${ }^{13}$ Bates, above n 1, 203.

${ }^{14}$ See, eg, Telstra Corporation Limited v Hornsby Shire Council (2006) 146 LGERA 10; Taralga Landscape Guardians v Minister for Planning (2007) 161 LGERA 1; Hub Action Group Inc v Minister for Planning (2008) LGERA 136 (Preston CJ). 15 (2008) 161 LGERA 136.

${ }^{16} \mathrm{M}$ Halle, Executive Director of the European Office of the International Institute for Sustainable Development, 'Rebooting Sustainable Development: Why it Hasn't Worked and What to do About it', (11 March 2010), <http://www.youtube.com/watch?v=j1iDxP2MDW>.
} 
accountable review of decisions made by public authorities regarding resources managed on trust for the public. $^{17}$

\section{Australia switches from the sheep's back to the mining pit}

Mining and minerals have been an intricate part of Australian culture, history and economic income since first settlement by the West. Within ten years of the First Fleet's arrival in 1788 to NSW, commercial mineral extraction began to take infant steps accelerating with gold rushes in Victoria and NSW. ${ }^{18}$ Mclntyre observes that ' $[\mathrm{t}]$ he goldfields were the migrant reception centres of the nineteenth century, the crucibles of nationalism and xenophobia, the nurseries of artists, singers and writers as well as mining engineers and business magnates'. ${ }^{19}$

Australian land use and its economic base in the $19^{\text {th }}$ and $20^{\text {th }}$ centuries, however, were derived predominantly from agriculture, timber and dairy industries, with the main commodity being wool. ${ }^{20}$ Nevertheless, environmental problems associated with mineral extraction, such as land clearing and pollution, began in those centuries as well. ${ }^{21}$ In the second half of the $20^{\text {th }}$ century, Australia transitioned from a dependant former British colony to 'a small rich industrial country'. ${ }^{22}$ Mineral discoveries in Western Australia led to the export of minerals to Asian markets and an oil discovery in the Bass Strait in 1966 propelled Australia to self-sufficiency (or dependency) on fossil fuels. Income from wool markets peaked in the post-Korean War era and shifted in trade from Europe to East Asia. 'Wool gave way to meat and wheat as chief farm exports but the largest foreign earnings came from energy and minerals' ${ }^{23}$

Mining continues to play a prominent part in the Australian economy and is firmly linked to economic development in Asia, especially China. ${ }^{24}$ Mining now accounts for around 10 per cent of Australia's GDP. ${ }^{25}$ As Australia has had a significant agrarian base, competing land uses are now coming into conflict with mining expansion. The 2012 International Handling Services (IHS) Global Insight Country Intelligence Report for Australia noted that:

conflict over land and water use between mining sector and agricultural sectors is expected to become a major issue over the medium term as the resource sector seeks additional resources to meet future demand from emerging Asia. ${ }^{26}$

That predicted conflict has now arrived and has played out in several instances in NSW. The next section of this article will demonstrate this by reference to the Bulga case. ${ }^{27}$

\section{The Bulga Case}

Approval for an application to extend its existing open-cut mine was granted to Warkworth Mining Ltd (Warkworth) close to the village of Bulga in the Hunter Valley by the Planning and Assessment Commission of NSW (PAC) as a delegate of the Minister for Planning and Infrastructure in early 2012. Conditions of the consent included biodiversity offsets to mitigate the adverse impacts of the mine extension on biodiversity including affected endangered ecological communities. Bulga residents exercised their right of appeal under s $75 \mathrm{~L}(3)$ of the EPA Act. Section $75 \mathrm{~L}$ was contained in the now repealed Part 3A of the EPA Act.

\footnotetext{
${ }^{17}$ See, eg, J Sax, Defending the Environment: A Strategy for Citizen Action (Vintage Books, $4^{\text {th }}$ ed, 1972) for concept of public trusts.

${ }^{18}$ S Mclntyre, A Concise History of Australia (Cambridge University Press, 199) 91.

${ }^{19}$ Ibid 90

20 Ibid 91.

${ }^{21}$ Ibid.

${ }^{22}$ Ibid 203.

${ }^{23}$ Ibid 240.

${ }^{24} \mathrm{C}$ Kent, 'Reflections on China and Mining Investment in Australia' (Speech delivered by the Assistant Governor to the Reserve Bank of Australia, Perth, 15 February 2013) <http://www.rba.gov.au/speeches>. See also C Taylor et al, Beyond the Boom: Australia's productivity imperative (August 2012) McKinsey Global Institute <http://www.mckinsey.com/insights/asia-pacific/australia_productivity_imperative>.

${ }^{25}$ R Gittens, 'Mining Boom too Big to go Bust Just Yet', Sydney Morning Herald (Sydney), 24-25 August 24 2013, 8; A Grant-Taylor 'A Snapshot of Mining in Australia' (2013) Spirit Regional Australia 95, 96.

${ }^{26}$ IHS, 'Global Insight Country Intelligence Report for Australia' (Report, IHS, 2012) accessed September 2013, 25 (now no longer available). ${ }^{27}$ Ibid.
} 
The appeal was filed in Class 1 of the jurisdiction of the Land and Environment Court of NSW (LEC). The role of the LEC was to hear the application afresh as if 'in the shoes of the decision-maker' 28 in deciding whether the application should be approved or not. On balance of all relevant matters contained in $\mathrm{s} 75 \mathrm{~J}$ of the EPA Act, the LEC rejected the application. The basis of the decision was that, although the extension would have produced some positive economic and social impacts for the broader community, this was outweighed by the significant adverse impacts in terms of loss of biodiversity, increased noise and dust, and loss of the amenity of community life. It was also held that the proposed conditions of consent were inadequate.

An appeal against the decision was lodged in the NSW Court of Appeal but the appeal was unsuccessful. ${ }^{29}$ Soon after the LEC hearing was concluded, the CEO of Rio Tinto, the parent company of Warkworth, argued in the media that the LEC should not have the power to review decisions about mining projects. ${ }^{30}$ The case received a great deal of media attention in Australia and overseas. ${ }^{31}$

A fresh application to expand the Warkworth mine for a smaller area has now been approved by Gary West and David Johnson of the PAC. Some public meetings were held in Singleton in December 2013 as a part of the assessment process. ${ }^{32}$ This process was less rigorous than the public participation built into the EIA procedure under Part 3A (now repealed) of the EPA Act. This involved advertisement of the EIA documentation, which included written comments from the public and a requirement for the decision-maker (Director of Planning) to take these comments into account in the decision about whether development approval would be given (or not) and the conditions of consent (if applicable). It is acknowledged that the meetings can assist in obtaining feedback. However it has been noted by Paddock ${ }^{33}$ that public engagement based on public hearings, public meetings and notice and comment rule-making procedures 'frequently do not create conditions necessary for effective or "authentic" public engagement and therefore fail to live up to their potential for enhancing environmental outcomes and producing more just decisions'.

There has been yet another application made to expand the Warkworth mine, to a similar extent as that rejected by the LEC, but with additional public benefits and biodiversity offsets offered by Warkworth. This application is still pending. ${ }^{34}$

\section{Backlash from the Bulga Case}

There were a number of negative reactions to the LEC decision on the Bulga case from the business community in addition to those by representatives of Warkworth and Rio Tinto. For example, a letter to the NSW Premier by the Chief Executive Officer of the NSW Business Chamber indicated the uncertainty the LEC decision had caused potential investors in NSW to rethink their options and invest elsewhere. ${ }^{35}$ The letter called for the NSW Government to join the appeal against the LEC decision and requested development of 'a reliable, transparent and effective major project system ... to ensure that major projects, investment and jobs can be secured within NSW'. ${ }^{36}$

\footnotetext{
${ }^{28}$ Land and Environment Court Act 1979 (NSW) s 17; Land and Environment Court, Practice Note - Class 1 Development Appeals, 30 April 2007.

${ }^{29}$ See Warkworth Mining Limited v Bulga Milbrodale Progress Association Inc [2014] NSWCA 105.

${ }^{30} \mathrm{H}$ Kenyon-Slaney, 'Keep Mining Approvals out of Court' Australian Financial Review (online) 14 October 2013, <http://www.afr.com/p/opinion/keep_mining_approvals_out_of_court_BQLg7EQ4eAC0XJTL5F330l>.

${ }^{31}$ Matt Siegel, 'Coal Mine Fight Embodies an Economic Struggle in Rural Australia', New York Times (online) 13 August 2013, <http://www.nytimes.com/2013/08/14/business/global/in-australia-signs-of-a-tilt-in-economicequilibrium.html?pagewanted\%3Dall\&_r=1\&>; Tim Lamacraft and Sally Block, 'Landmark Court Case Begins Over Disputed Coal Mine Near Singleton', ABC Online, 14 August $2013<$ http://www.abc.net.au/news/2013-08-14/landmarkcourt-case-begins-over-disputed-coal-mine-near-singlet/4886826>.

32 See, eg, Planning and Assessment Commission, 'NSW Planning and Assessment Commission Determination Report Warkworth Coal Mine Modification 6’ (29 January 2014) <http://www.pac.nsw.gov.au/Projects/PACDeterminations/ tabid/104/ctl/viewreview/mid/459/pac/358/view/readonly/myctl/rev/Default.aspx>; M Chambers, 'Rio coal project hit by dollar, red tape' The Australian (online) 13 July 2013, <http://www.theaustralian.com.au/business/miningenergy/rio-coal-project-hit-by-dollar-red-tape/story-e6frg9df-1226678683696\#>.

${ }^{33}$ L C Paddock, 'The Role of Public Engagement in Achieving Environmental Justice' in Le Bouthillier et al (eds), Poverty Alleviation and Environmental Law (Edward Elgar, 2012) 133.

${ }^{34}$ Michelle Harris, 'Rio Takes a Fresh Tilt at Mine Extension', Newcastle Herald (Newcastle), 21 March 2014, 24; Peter Ker, 'Rio has a New Bid for Hunter', The Sydney Morning Herald (Sydney), 20 March 2014, 22.

${ }^{35}$ Letter from the Chief Executive Officer of the NSW Business Chamber to the Premier of NSW, 21 May 2013.

36 Ibid.
} 
The NSW Business Chamber was successful in its lobby - the NSW Minister for Planning and Infrastructure joined with Warkworth in the appeal against the Bulga decision and by late July 2012, a new mining SEPP (Amended Mining SEPP) was proposed; ${ }^{37}$ as it was delegated legislation, the usual debate process in Parliament for proposed legislation was largely absent. Under s 38(2) of the EPA Act, the relevant Minister has the discretion to seek and consider submissions from the public on environmental planning instruments (including SEPPs). In the case of the Amended Mining SEPP, despite the significance of the changes to the environmental assessment of mining projects, any comments had to be made within two weeks, which excluded any effective public participation.

The former Resources and Energy Minister, Mr Chris Hartcher, stated that the Amended Mining SEPP would ensure all considerations would be taken into account. He argued:

\begin{abstract}
W]hile the assessment of major projects has always been about balancing their economic and employment significance against any potentially adverse impacts, there have been no clear guidelines ... [T] he proposed amendments will provide clear direction to both the industry and the community in respect of the approvals process for mining projects. ${ }^{38}$
\end{abstract}

The Chief Executive of the NSW Minerals Council agreed with this. ${ }^{39}$ Other interest groups claimed that the Amended Mining SEPP would ensure that decision-makers would be able to give priority to economic considerations in decisions made about mining projects. As the Amended Mining SEPP requires that the significance of resources is the principal factor, it appears that environmental considerations are secondary matters for the decision-makers to consider. ${ }^{40}$

Notwithstanding the interpretation by the former Resources Minister and the NSW Minerals Council, the Amended Mining SEPP appears to be an attempt by the Executive to fetter the decision-making process and indirectly exclude public participation.

\title{
Other developments - Planning Bill 2013
}

The proposed overhaul to the planning process is indicated by the tenor of the proposed Planning Bill $2013,{ }^{41}$ which is set to promote economic interests over environmental and social interests, and generally reduce opportunities for public participation, especially in relation to major projects. Several examples of this reorientation away from a proper application of the triple bottom line approach include:

- Title - The long title of the Planning Bill states that 'it relate[s] to planning and sustainable growth in New South Wales', yet there is no mention of environment.

- $\quad$ Objects - The Planning Bill does not refer to the application of ESD to decision-making as the EPA Act does in $\mathrm{s} 5$. The objects of the Planning Bill are about enabling development based on narrower concepts of sustainable growth and sustainable development (Clauses 1.3(a) and 2). Protection of the environment is restricted to the promotion (rather than protection) of biodiversity conservation and sustainable management and conservation of heritage (Clauses 1.3(f)(i) and (ii)).

- Community Participation Charter - The Planning Bill does make ambitious claims for community involvement at the strategic planning and assessment stage but details of how that is to be achieved is unclear. Public engagement is included in an object in $\mathrm{cl} 1.3(\mathrm{i})(\mathrm{c})$, but appeal opportunities are very limited - for example, by restricting the review to the LEC for objectors to EIS-assessed development, in Clause 9.2(3). Planning provisions cannot be questioned after three months after the date of publication on the planning portal. The management of publication details on this portal are not included in the clause. ${ }^{42}$

${ }^{37}$ State Environmental Planning Policy (Mining, Petroleum, Production and Extractive Industries Amendments (Resource Significance) 2013.

${ }^{38}$ The Hon Chris Hartcher MP, former Minister for Resources and Energy, Special Minister of State and Coast, 'Improving Certainty for the Community and Investors in Mine Proposals' (Media Release, 29 July 2013).

${ }^{39}$ NSW Minerals Council, Submission to NSW Planning and Infrastructure, Mining State Environmental Planning Policy (Mining, Petroleum Production and Extractive Industries) Amendment (Resource Significance), August 2013, <http://www.nswmining.com.au/NSWMining/media/NSW-Mining/Publications/130812_NSWMC-Submission_MiningSEPP-amendments FINAL.pdf>.

${ }^{40}$ Environmental Defender's Office NSW, Submission to NSW Planning and Infrastructure, State Environmental Planning Policy (Mining, Petroleum Production and Extractive Industries) Amendment (Resource Significance), 2013.

${ }^{41}$ Planning Bill 2013 (NSW).

${ }^{42}$ lbid cl 10(ii)(2). 
Community involvement will focus on strategic planning rather than specific development proposals. This makes it more likely that public participation opportunities would be reduced as the public generally find it more difficult to conceptualise specific social, environmental and economic impacts that strategic planning concepts will have as opposed to particular development proposals. The Environmental Defender's Office of NSW notes 'the general public are only energised to engage with planning when they hear about actual local projects, not hypothetical future developments'. ${ }^{43}$

The focus on involvement by the public at the strategic planning level has resulted in the absence of community rights to be consulted or to object to decisions once strategic planning is complete. Merit review rights for the public will not be available for state significant developments (which include mining projects) where the Planning and Assessment Commission holds a formal public hearing (cl 9.6(3)(a)).

Clause 10.12 of the Planning Bill has significantly limited the 'open standing' rights (such as in the present $\mathrm{s}$ 123 of the EPA Act) including legal errors of decision-makers in the LEC in relation to community participation strategic plans and approvals for public priority infrastructure, state significant developments and state infrastructure developments.

\section{The future}

There are global initiatives being developed to encourage decision-makers to maintain a proper balance between economic, social and environmental considerations to be taken into account in decision-making. These initiatives suggest a preferable approach to the conflict outlined in the Bulga case. In his opening remarks to an Australia forum on business leadership, His Royal Highness Prince Charles observed that the primary position of Australian corporate initiatives is to balance economic growth with environmental protection and social interests. ${ }^{44}$

Such an approach is found in initiatives such as the Global Compact Network, ${ }^{45}$ developed to assist Australian signatories to the UN Global Compact to integrate and give effect to the Ten Principles relating to issues such as human rights, environment, labour and anti-corruption, which support broader United Nations goals. With respect to the environment, businesses and governments should take a precautionary approach, undertake greater environmental responsibility and encourage development of environment-friendly technologies.

Another relevant initiative is the World Business Council for Sustainable Development 2050 Vision. This is the combined effort of 29 companies across 14 industries engaged in dialogue with 200 companies and experts in 20 countries, which agree that the Business As Usual approach is not an option. The essential approach is to incorporate the true cost of externalities into development proposals. The 2050 Vision supports public participation by 'encourage[ing] and facilitat[ing] stakeholder accreditation and preparation of major policy decisions'. ${ }^{46}$ Companies who subscribe to these principles should not just include this commitment on their Corporate Social Responsibility and Annual Reports statements but reflect it in their activities and investments.

Policies, programmes and legislative reforms should be developed to recognise and give effect to the vital role of public participation in ensuring sustainable development and assisting in achieving better environmental decision-making outcomes.

\section{Conclusion}

Development of non-renewable resources is inevitable but it must be carefully monitored by the EIA process and responsible decision-making based on a triple bottom approach. The EIA should be open to review by

\footnotetext{
${ }^{43}$ EDO 'NSW Submission on A New Planning System for New South Wales - White Paper' (EDO, June 2013) 29, <http://www.edonsw.org.au/planning_reforms>.

${ }^{44}$ HRH Prince Charles, 'Plenary Address to Business Leadership in the New Global Innovation Economy: The Race Is On' (Business Leaders Forum on Sustainable Development, Parliament House, Canberra, 16-17 June 2011). See also Deloitte, Tracking the trends 2013: the top 10 issues mining companies may face in the coming year (2013) Deloitte <https:/ /www.deloitte.com/assets/DcomSouthAfrica/Local\%20Assets/Documents/Tracking\%20trendsFINAL\%20localisedpdf.pdf > . ${ }^{45}$ United Nations Global Compact, above $\mathrm{n} 12$.

${ }^{46}$ World Business Council for Sustainable Development, 'Vision 2050: The new agenda for business' (Report, WBCSD, 2010).
} 
the public - the larger the project the more rigorous the EIA process should be. The public should have rights to be involved in the decision-making enshrined and protected in legislation.

Judicial review as a basic tenet of the separation of powers and the rule of law should not be excluded by legislation and actions by the Executive. The judiciary should be protected against attack by stakeholders in the community due to their perception that the legal system acts against their economic interests. Access to justice must be safeguarded from legislative and regulatory amendments which are not filtered by regulatory impact statements to determine the true, social and environmental costs of future developments, particularly mining.

Innovative programs have been developed at all levels in government in some states of the USA, such as California, Florida, Indiana and New Jersey in California, proposed legislation, such as the Californian Assembly Bill and the Californian Senate Bill 32, creates programs to address the disproportionate health and environmental impacts suffered by poorer communities, and mandates public participation and outreach necessary to help affected communities to understand the process of cleaning up hazardous waste. The Clearwater Florida Brownfields Redevelopment project used an innovative public engagement method to address environmental justice issues related to contaminated sites covering nearly 2000 acres. This method was community driven 'using a collaborative community-based planning approach'. The Clearwater Initiative could be examined to develop a better public engagement model in Australia by including these features in legislative protection of public participation.

Another practical approach is to use regulatory review ${ }^{47}$ processes 'to create a framework for creating fairer environmental laws, enabling a transparent debate about the social impact of regulatory proposals'. Martin $^{48}$ proposes formal regulatory social impact assessment together with a comprehensive explanation in a regulatory impact assessment. This approach may have lessened or avoided the controversies leading to the Bulga case.

${ }^{47}$ Paddock, above $\mathrm{n} 33,147-148$ (list of ideal features of effective public engagement).

${ }^{48} \mathrm{P}$ Martin, 'Embedding social justice in the design of environmental regulation' in Poverty Alleviation and Environmental Law, above n 33, 194-195. 